ESSAY REVIEW

\title{
Historical Views of Spiritism and Mediumship in Spain, 1880-1930
}

Ciencia y Espiritismo en España, 1880-1930 [Science and Spiritism in Spain, 1880-1930] by Andrea Graus. Comares, 2019. viii + 134 pp. $€_{14}$ (paperback). ISBN 978-84-9045-898-3.

\section{Reviewed by Carlos S. Alvarado}

carlos@theazire.org

https://10.31275/20211843

Creative Commons License CC-BY-NC

\section{INTRODUCTION}

Little is known by non-Spanish speakers about the history of Spiritism and psychical research in Spain. Standard English-language sources such as Frank Podmore's Modern Spiritualism (1902) and Arthur Conan Doyle's The History of Spiritualism (1926) do not cover developments in that country. ${ }^{1}$ There is a useful historical outline of the topic in philosopher and educator Mario Méndez Bejarano's Historia de la Filosofía en España Hasta el Siglo XX (n.d., Chapter 17, Part 14). Much of relevance can be found in the new historiography about the subject in Spain which, like that in some other countries, has grown in recent decades. ${ }^{2}$ Other recent studies have included psychical research as well. Particularly useful are the essays compiled by Annette Mülberger (2016) in Los Límites de la Ciencia: Espiritismo, Hipnotismo y el Estudio de los Fenómenos Paranormales (1850-1930), and articles about such topics as the attitudes and approaches of specific investigators (Vilaplana Traviera \& Mülberger, 2003), turning tables (González de Pablo, 2006), and prominent clairvoyance studies (Mülberger \& Balltondre, 2013). Andrea Graus, the author of the book reviewed here, has also made various significant contributions.

Graus, a historian at the Centre Alexandre Koyré, has published 
various articles about mediumistic investigations, and the ideas of Spanish physicians (e.g., Graus, 2015, 2016). This work has been expanded in the book reviewed here, Ciencia y Espiritismo en España, 1880-1930 (see Figure 1).
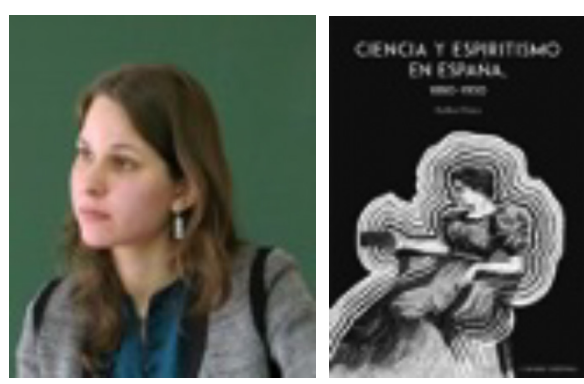

Figure 1. Andrea Graus and her book.

Spiritism developed in the second half of the nineteenth century in Spain, following the line of Allan Kardec, who was particularly influential in France (Sharp, 2006). From the 1850 s on, several Spanish mediums and students of the subject appeared. The Catholic Church must have felt the movement was growing too much, when on October 9, 1861, they burnt more than 300 spiritist books in Barcelona that came into the country illegally for a French librarian who resided in the city. ${ }^{3}$

By 1888 , when the first of various later international spiritist congresses was held in Barcelona, spiritists included important leaders such as writer Amalia Domingo y Soler (Figure 2), notary José María Fernández Colavida, philosopher Manuel Sanz Benito, and politician and journalist Viscount Antonio de Torres Solanot y Casas, all of whom took part in the congress (Primer Congreso, 1888).

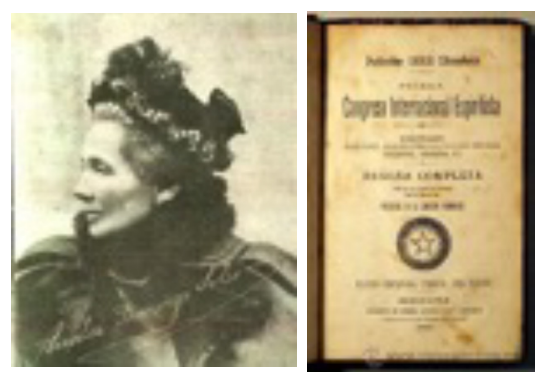

Figure 2. Amalia Domingo y Soler and the cover of the proceedings of the first international Spiritism congress in Barcelona, 1888.

future life" (Torres Solanot, 1875, p. 69, italics in the original; this, and other translations, are mine). This author stated he did not want to leaders, the movement came to answer the questions raised in an age of criticism and skepticism, questions that neither science, nor philosophy, nor religion could answer. Spiritism was a "new element of progress" that arrived at "the twilight of a passing age, and it is the dawn of a coming age" which "puts us in connection with the invisible world, showing us the

As stated by one of these 
impose a belief but instead to invite people to study and experiment. His writings, however, do not show a scientific approach, but rather a missionary perspective that was common among other nineteenthcentury writers, both in Spain (Navarro Murillo, 1873-1874) and in other countries (e.g., Brittan, 1851).4 The individuals covered in the book reviewed here attempted to redefine Spiritism in Spain along more scientific lines.

\section{GRAUS' BOOK}

The author states that "by the end of the XIX century there was a slow appropriation of mediumship from the scientific area, especially within psychiatric and psychological domains" (p. 7). A new conception of mediumship emerged that saw the phenomena as the result of the powers of the living medium, as opposed to discarnate agency. The phenomena "were caused by man, be they through unknown faculties or by natural forces that mediums were able to channel" (p. 7). The book is to some extent about representatives of these ideas in Spain.

Later in the book Graus briefly reviews the psychological, and particularly clinical, approach to mediumship, arguing that the "development of theories about automatism, multiple personalities, or altered states of consciousness was strongly influenced by the study of spiritist mediums, who were transformed into subjects of psychological investigation"(pp. 35-36). This idea has generated a specialized literature that has appeared in forums other than those devoted to history (e.g., Alvarado et. al., 2007).

The discussion includes mention of several pioneering nonSpanish writings about the pathology of mediums, such as the ideas about dissociation of French psychopathologist Pierre Janet (p. 41). Janet stated in his classic work L'Automatisme Psychologique (1889) that the majority of mediums "are neuropaths, when they are not frankly hysterics" (p. 404). Interestingly, and illustrating Graus' general outlook, an examination of Janet's book shows that he was influenced by psychical researchers. Janet cited the work of well-known English classical scholar and psychical researcher Frederic W. H. Myers to provide examples of dissociation and the phenomena of mediumship (Janet, 1889, pp. 78, 121-122, 135-136, 371, 392-394, 403, 405, 415-419). 
He used this material, and writings from spiritists, to provide examples of mediumistic communications in order to construct his model of dissociation, an example of influence from a marginal discipline to a more established one. But the use of Myers' ideas was selective, that is, Janet stripped them from their supernormal component and kept those aspects of it that did not conflict with his views. Incidentally, although Janet did not agree with Myers in several ways, he recognized that Myers had presented a model of dissociation that was more developed than what had been published before (Janet, 1889, p. 403).

Graus starts the first chapter with physician Manuel Otero Acevedo (1865-1920; see Figure 3), who was born in Argentina but was educated and worked mainly in Spain. Initially a self-confessed materialist and
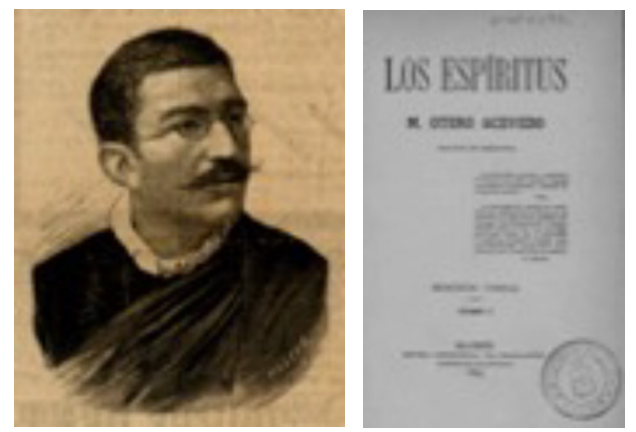

Figure 3. Manuel Otero Acevedo and his book Los Espíritus. a skeptic, this physician eventually accepted the reality of psychic phenomena via his own observations and study of the work of others. For example, he conducted observations about mental suggestion and had séances with Eusapia Palladino that convinced him that her phenomena were real. The latter were mentioned in the second volume of his book Los Espíritus (Otero Acevedo, 1893-1895). Otero had séances with the medium in Naples in 1888 and 1889. In a section of the book (Vol. 2, pp. 217-255) he classified the phenomena he observed as complete and partial levitations with the medium touching the table; complete and partial levitations of a table when the medium was not touching the table; action on distant objects; changes of weight in tables; levitation of the medium; direct writing; luminous phenomena (small lights and materialized forms); and impressions of fingers, hands, and faces on plaster. Anyone familiar with the literature about this medium will realize that similar effects were reported by many others in later years (e.g., Carrington, 1909).

Otero several times saw violent movements of the séance table. On one occasion he made the medium kneel on a chair and put 
both hands inside two cups full of water, hoping to control for hand movements, but the table still moved around. He wrote:

[The table] responds to questions I ask with movements and blows, and in turn asks if I am satisfied with the event ... A notable peculiarity: The cups remain firm despite the swings of the table, as if they were attached to the wood ..." (Otero Acevedo, 1893-1895, Vol. 2, p. 221)

The reports of materialized forms were even more impressive. In one of them, Otero reported that the medium started saying her spine was hurting, and she got nervous, yelled and writhed, and the curtains of the mediumistic cabinet moved. He wrote:

The curtain is shaken again and at the door appeared the outline of an arm that lengthened and quickly withdrew; waves its hand as if saying hello, and disappears. Immediately it leans out by the edge of the curtain, and at a height that corresponds to the screen in the room [a lamp screen], the silhouette of a head, visible up to the neck ... The arm comes out again, the head makes some movements and a shadow crosses the door. The head reappears on the opposite side to the one that it previously occupied, and taking a bow disappeared. (Otero Acevedo, 1893-1895, Vol. 2, pp. 246-247)

Interestingly, Graus makes a comparison between Otero and Lombroso, who shared some correspondence. They both started their study of mediums through Palladino and with an ingrained materialist conviction. This led them to deny, a priori, the spiritist hypothesis. Lombroso was influenced by German materialism and tried to give a physiological explanation for mediumistic phenomena. Both of them attempted to place the phenomena observed with Palladino within "official science," but when they could not find a satisfactory explanation that could account for all the facts, they reached the conclusion that there existed phenomena that seemed to explain the existence of spirit (p. 32).

Also interesting, but beyond the scope of this study, is a topic I have discussed before. I am referring to the influence of individuals such as mediums who generate phenomena, in this case the impact that Palladino had on the development of psychical research (Alvarado, 
1993). This included converting many individuals to the belief in real physical phenomena, and, in the case of some, of spiritualistic interpretations. Furthermore, this medium exerted much influence on theoretical ideas of psychic forces via her phenomena and behaviors (in interaction with the ideas and agendas of researchers), and in generating for many people negative images of séance phenomena.

The second chapter is about the physician Víctor Melcior i Farré (1860-1929), from the province of Lleida, in Catalonia (see Figure 4). He represented what Graus refers to as an interest that instead of

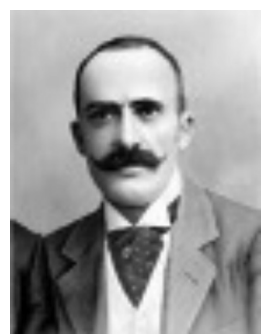

Figure 4. Víctor Melcior i Farré. emphasizing spirit action, concentrated on "the interior aspects of the medium, in her subconscious, to try to find the natural cause, psychophysiological, of the spiritist marvels unexplained by science" ( $p$. 36). However, Melcior's approach, as Graus says, differed from the point of view of psychopathologists like Pierre Janet. While Janet only believed in pathology, and not in veridical mental and physical manifestations, Melcior believed in the coexistence of pathology and real phenomena in mediums. This is a conceptual tradition upheld by a few theoreticians, as I have argued in the case of Jules Bernard Luys' ideas of "magnetic" pathology and Cesare Lombroso's explanations of Palladino's physical phenomena (Alvarado, 2019; Alvarado \& Biondi, 2017). Interestingly, Graus states that Melcior defended reincarnation following Kardec's ideas (p. 37).

The author writes that Melcior believed that mediumistic communications, and the personality changes in mediums, were explained by dissociation, and the physical phenomena by the projection of vital force from the body of the medium. Neither process involved spirits of the dead. Graus writes:

According to Melcior, the irradiation of such force did not always manifest with the same intensity, which allowed [him] to classify the subjects into three "psychic types": the weak, the medium, and the strong. ... Melcior defended this stance saying the instability of character and weakness of will facilitated this process ... [and he argued that] the passing of psychological doubling to the physical depended on the degree of irradiation of the psychic force. In lower levels it induced creaks, movement of objects, levitation, or appari- 
tions of lights. And last: "in the superior degree of doubling there comes out the phantasmal body of a living person, moving to more or less remote places, and coming to be recognized by the person or persons to whom it appears." (pp. 51-52)

Graus is right to relate these ideas to those of Albert de Rochas, who argued that the exteriorization of forces from the body was associated with a fluidic body or double. This had four phases of the exteriorization of a double, the last one being a physical materialization of a human body. This, according to de Rochas, consisted of "a galvanoplastic transport of the matter of the physical body of the medium, matter that comes from the physical body to occupy a similar position on the fluidic body" (de Rochas, 1897, p. 27).

We are introduced to astronomer Josep Comas i Solà (1868-1937; see Figure 5) in the third chapter, and to his séances with medium Carmen Domínguez, who produced, among other phenomena, materializations. While the astronomer may have wanted to bring mediumistic phenomena into science, Graus argues that the spiritists had their own agenda. In her words: "The spiritists did not get in contact with him so that we would confirm the reality of the phenomena, but that, through his authority, he would legitimize them within the scientific sphere" (p. 85). Unfortunately, the whole enterprise did not go well, for Comas accused the

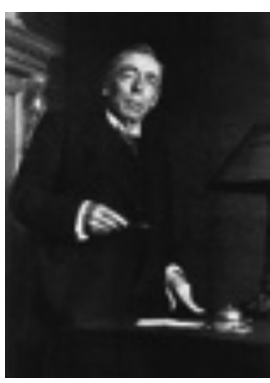

Figure 5. Josep Comas i Solà. medium of fraud, and he entered into controversies about her and the proper way to study mediums, a topic he discussed in his book El Espiritismo ante la Ciencia (n.d.).

In this book, Comas argued that the scientific study of natural phenomena would always be legitimate. But a science "based on the study of phenomena that flow from the consciousness of man is condemned, due to its origin, to the infamy of lies" (Comas i Solà, n.d., p. 21), by which he referred to fraud. Interestingly, he went on to discuss physical ideas of matter and energy, from which he speculated on the mechanisms of mediumistic materialization, a phenomenon he did not seem to believe in. In his book, Comas started out assuming that the body of the medium showed a "lack of cohesion or a lack of unity 
in its organism" (p. 87) that involved the projection of an "individual" from the medium's body. This "new imponderable and invisible individual, completely or partially away from the medium, would have the same forces and the same mentality of the medium, but necessarily diminished" (p. 88) and be similar in shape to the medium's body.

In the fourth chapter we are introduced to physician Humbert Torres i Barberà (1879-1955; see Figure 6), who was in contact with

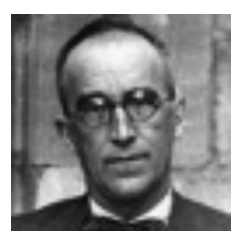

Figure 6.

Humbert Torres

i Barberà. French psychical researchers and studied the medium Marcelle Morell. Graus points out that Torres was educated in French metapsychics, and she provides a brief overview of such developments (pp. 92-101).

Torres presented a series of public lectures in 1926 that show he was well-acquainted with the international psychical research literature (De Todas Partes, 1926). The first part, consisting of three presentations, was about phenomena produced by the living, among them telepathy, exteriorization of sensitivity, telekinesis, and materializations. The second part was about phenomena suggestive of discarnate agency. This had two lectures about various mediumistic phenomena and recollection of previous lives. ${ }^{5}$ The first included mechanical (table movements and raps), graphic (photographs, automatic writing), spoken (possession, direct writing), plastic (apparitions, materializations) and various other kinds of phenomena (book tests, hauntings).

Graus comments than one of the strategies the French used to separate themselves from Spiritism was a change of terminology, which presented "a view of mediumship that can be defined as 'properly' metapsychic, in that it is destined to show the limits of this field and to be demarcated from Spiritism" (p. 97). This view, I believe, is consistent with Charles Richet's definition of metapsychics without reference to spirits or nonphysical processes. He proposed calling metapsychics "a science which has as its object mechanical or psychological phenomena due to forces which seem intelligent, or to unknown powers latent in human intelligence" (Richet, 1922, p. 5, italics in original removed). However, Torres was open to discarnate agency as an explanation.

In this chapter Graus presents two organizations that represented attempts to organize metapsychics in Spain. These were the Instituto de Metapsiquismo de Barcelona (founded in 1923) and the Sociedad 
Española de Estudios Metapsíquicos de Madrid (founded in 1924). Both were short-lived and consequently not able to provide much institutional support for psychic investigations. The first one was seen by some of its founders as an attempt to use the scientific investigation of psychic phenomena to assist Spiritism, but it does not seem to have produced research. The second group was founded by Joaquín María Argamasilla de la Cerda y Bayona (1870-1940), known as the marquis of Santa Cara, who believed his son was a clairvoyant. ${ }^{6}$ Graus states that, unfortunately, very little of the work of this organization was published. In fact, she suggests that the purpose of the group may have been for Santa Cara to establish his position as the main representative of metapsychics in Spain.

The Sociedad published a journal, Revista de Estudios Metapsíquicos, that defined the agenda of the organization as that of atheoretical experimental investigations of psychic phenomena. Announcements appeared in the journal asking the public for information about and access to individuals with psychic faculties. This reminds me of the situation at the beginning of the Society for Psychical Research in London. A letter appeared in The Times (of London) on Christmas day of 1883, asking for cases of various types of psychic phenomena to be sent to Edmund Gurney or to Frederic W. H. Myers (Advertisement, 1883). Similarly, the Proceedings of the Society also asked members to conduct thought-transference experiments, and to send information about mediums and haunted houses, as well as published accounts of psychic phenomena found in biographies and in other published sources (To Members, 1883).

Graus reminds us that, in Spain, the relationship between academic psychology and metapsychics was affected by the nascent state of the first discipline. This led some psychologists to engage in boundary work to demarcate between metapsychics and psychology. Here the author introduces the work of psychologist and Jesuit priest Father Fernando María Palmés (1879-1963), who was a strong enemy of metapsychics. "Together with psychologists such as Jastrow in the United States, he argued that only those who were experts in experimental psychology could judge the reality of spiritist phenomena and he assumed the role of guardian of scientific knowledge" regarding metapsychics and Spiritism (p. 113). His attitude, continues 
Graus, shows that "psychology in Spain still was on fragile ground and struggled for its own scientific legitimacy" (p. 113).

\section{SUMMARY}

Graus' book is a valuable contribution to the historiography of both Spanish psychical research and mediumship. Her discussions of the above-mentioned individuals not only enlarge our knowledge of specific investigations and ideas, but also show that the researches she focuses on were connected with what was happening in other countries.

In addition to the individuals she focuses on, Graus also rescues from oblivion other figures such as the above-mentioned Palmés. This is important because in giving space to Palmés she reminds us that the history of psychical research is not only the study of the work of proponents for the reality of the phenomena, but also includes critics, something that is not always recognized by contemporary parapsychologists.

Furthermore, she notices that there is no evidence of connections between the various research projects, or of important institutional developments, even though she mentions some organizations. The fact that their work took place outside academia did not lead the researchers to consider that their work was not scientific. They instead hoped for the development of a new field of study based mainly on the study of mediums. "In this sense, they believed that the investigation of mediums could mean an advance in scientific knowledge, and trusted that their work would one day be recognized as pioneering" (p. 116).

The author also, rightly in my view, questions the use of the term pseudoscience.

From the historiographic point of view, to be interested in Spiritism and in psychical research is not to ask oneself what turns these fields pseudoscientific, or if they are the mere product of a fraud. The history of the so-called pseudosciences is . . a a way of getting closer to science, of understanding how knowledge functions in this context and to investigate how scientists mark their terrain and assume positions in society. (p. 117)

Furthermore, Graus sees that the persons she discussed contrib- 
uted to scientific knowledge during difficult times. That is, when their topics were being highly criticized and when the "professionalization of science defined what and who formed part of a scientific domain" (p. 117).

Graus presents a valuable contribution to the history of psychical research in her discussion of the work and ideas of the abovementioned men, individuals who have not been well-represented in the international historiography of the subject. She argues at the end of the book that she is not saying that the persons discussed in the book were eccentrics who were simply deceived by mediums. Regardless of the neglect of their work by science at large, these researchers "contributed to the production of a different kind of scientific knowledge, particularly psychological and psychiatric" (p. 117). In conclusion, Graus writes that the role of history is not to determine if a field is pseudoscientific, or if fraud is a likely explanation. In her view the history of the so-called pseudosciences is a way to approach science (p. 117).

Graus' focus on mediumship, and other phenomena, does not emphasize Otero's interest in showing the universality of psychic phenomena in the history of humankind. This is the topic of the first volume of his work Los Espíritus (Otero Acevedo, 1893-1895), where he discussed belief and interest in psychic phenomena in past civilizations, such as those of the Assyrians, Chaldeans, Egyptians, Etruscans, Greeks, Hebrews, Indians, Phoenicians, and Romans. Such a massive undertaking is part of a rhetorical tradition present in mesmeric and spiritualist writings to support the reality and importance of psychic phenomena by showing the universality of cases and beliefs across time and cultures (Alvarado, 2014). Otero argued that the then current trends to neglect and deny psychic phenomena show how little humanity has learned about its own history. In his view: "Known from the most remote antiquity, in the first civilizations of which news is preserved today, they have subsisted in all ages, in all times and in all peoples, because they are a manifestation of human organization" (Vol. 1, p. 29).

It should also be mentioned that the second volume of Los Espíritus helped to publicize in Spain investigations of various individuals from other countries. There are chapters about the work and ideas of William Crookes, Johann C. F. Zöllner, Aleksandr Aksakov, Ercole Chiaia, and Paul Gibier (Chapters 1-5, respectively). This allows us to see a further 
dimension of Otero's work, that of popularizer and reviewer of the history of psychical research. A further example is a series of 12 articles that were published in the Spanish newspaper El Heraldo de Madrid, in which the author discussed topics such as apparitions of the living, materializations, mental suggestion, and the physical phenomena of Eusapia Palladino (Otero Acevedo, 1891).

\section{CONCLUDING REMARKS}

There are several minor inconsistencies regarding what certain authors said, and I have some disagreements with some statements, but these shortcomings don't detract from the overall value of the book, the importance of her historical study, or her conclusions. Her work is a pioneering one that I hope will inspire other research efforts in Spain. To restate, Ciencia y Espiritismo en España, 1880-1930 not only informs us about investigative and theoretical developments in Spain that are generally unknown even to those interested in the histories of Spiritism and psychical research, but it also illuminates social aspects of that history, such as the main figures, their relation to local spiritists, and contacts with foreign figures. The study also shows the existence of Spanish theoretical ideas of pathology, the unconscious mind, and unorthodox concepts of force. All of this shows the influence of foreign concepts (mainly French), and the commonality of conceptual and methodological issues in the international study of mediumship.

\section{NOTES}

1 For example, Spain is not represented in more recent overviews of spiritualistic and psychical research topics such as Beloff's (1993) general history of parapsychology and Moreman's (2013) anthology of articles about spiritualism and psychical research.

2 Some examples include Abend (2004) and Balltondre and Graus (2016).

3 The burned materials included issues of Revue Spirite, Revue Spiritualiste, and books by Allan Kardec, as well as by authors such as Ermance Dufaux, A. Grand, and Ludwig von Guldenstubbe (La Queue, 1861). In the anonymous article its author (probably Kardec), 
said that it seemed a dream that the fires of the Inquisition were still burning in 1861 (p. 321). In addition, this author also wrote: "Thanks to this reckless zeal, everyone in Spain will hear about Spiritism and will want to know what it is ..." (p. 323). Writing in a Spanish newspaper, an anonymous author considered the book-burning an indication of hypocrisy, fanatism, and barbarism (Untitled Article, 1861).

4 In other publications Torres-Solanot (1872) recognized the value of empirical studies of psychic phenomena.

5 Torres (1923) had previously published an article about reincarnation in which he classified cases in terms of recollections in the waking state, those that were announced via visions, dreams, and spirit communications, and those in which details were given through hypnosis and mediumship.

6 Santa Cara's son, Joaquín María Argamasilla de La Cerda y Elio (19051985), received much publicity in Spain and was tested at the Institut Métapsychique International (Mülberger \& Balltondre, 2013). For a prominent accusation of fraud outside of the Spanish context, see Houdini (1924). Santa Cara (n.d.) was known in Spain for his studies with clairvoyants.

7 For a discussion of Father Palmés, see Mülberger et al. (2001). I would argue that Palmés' work represents the agendas of at least two groups. $\mathrm{He}$ represented psychologists and others who built boundaries between established and unorthodox knowledge regarding psychic phenomena (Brown, 1983; Coon, 1992). In addition, he was part of a tradition of Catholic (and generally Christian) opposition to psychic phenomena, sometimes labelling them as satanic. This opposition is discussed in the context of other countries by Biondi (2013, Chapter 3) and Sharp (2006, pp. 140-145). It must be clarified that not all this opposition came from the clergy, and that many members of the clergy have been positive about the existence of psychic phenomena (Nicol, 1966).

\section{REFERENCES}

Abend, L. (2004). Specters of the secular: Spiritism in nineteenth-century Spain. European History Quarterly, 34(4), 507-534. https://doi.org/10.1177/0265691404046545 [Advertisement]. (1883, December 25). The Times, p. 1.

Alvarado, C. S. (1993). Gifted subjects' contributions to parapsychology: The case 
of Eusapia Palladino. Journal of the Society for Psychical Research, 59(833), 269-292.

Alvarado, C. S. (2014). On constancy, stability and the antiquity of psychic phenomena. Paranormal Review, 69, 3-7.

Alvarado, C. S.(2019). Jules Bernard Luys on magnetic pathology(Classic text no. 119). History of Psychiatry, 30(3), 359-374. https://doi.org/10.1177/0957154X19830955

Alvarado, C. S., \& Biondi, M. (2017). Cesare Lombroso on mediumship and pathology (Classic text no. 110). History of Psychiatry, 28(2), 225-241. https:// doi.org/10.1177/0957154X16686904

Alvarado, C. S., Machado, F. R., Zangari, W., \& Zingrone, N. L. (2007). Perspectivas históricas da influência da mediunidade na construção de idéias psicológicas e psiquiátricas. Revista de Psiquiatria Clínica, 34 (supp. 1), 42-53. https://doi. org/10.1590/s0101-60832007000700007

Balltondre, M. \& Graus, A. (2016). The city of spirits: Spiritism, feminism and the secularization of urban spaces. In O. Hochadel \& A. Nieto-Galan (Eds.), Barcelona: An urban history of science and modernity, 1888-1929 (pp. 136-157). Routledge.

Beloff, J. (1993). Parapsychology: A concise history. Athlone Press.

Biondi, M. (2013). Spiritualism in Italy: The opposition of the Catholic church. In C. Moreman (Ed.), The spiritualist movement: Speaking with the dead in America and around the world (Vol. 1, pp. 37-53). Praeger.

Brittan, S. B. (1851). Spiritualism: Its nature and mission. The Shekinah, 1(1), 1-12.

Brown, E. M. (1983). Neurology and spiritualism in the 1870s. Bulletin of the History of Medicine, 57(4), 563-577.

Carrington, H. (1909). Eusapia Palladino and her phenomena. B. W. Dodge.

Comas i Solà, J. (n.d., ca. 1908). El espiritismo ante la ciencia: Estudio crítico sobre la mediumnidad. F. Granada.

Coon, D. J. (1992). Testing the limits of sense and science: American experimental psychologists combat spiritualism, 1880-1920. American Psychologist, 47(2), 143-151. https://doi.org/10.1037/0003-066X.47.2.143

de Rochas, A. (1897). Les expériences de Choisy-Yvrec (près Bordeaux) du 2 au 14 octobre 1896. Annales des Sciences Psychiques, 7, 6-28.

De Todas Partes. (1926). Lumen, 31 (April), IX-X.

Doyle, A. C. (1926). The history of spiritualism (2 vols.). Methuen.

González de Pablo, A. (2006). Sobre los inicios del espiritismo en España: La epidemia psíquica de las mesas giratorias de 1853 en la prensa médica. Asclepio, 58(2), 63-96. https://doi.org/10.3989/asclepio.2006.v58.i2.22

Graus, A. (2015). Los prodigios del hombre encarnado: Víctor Melcior y la redefinición de la mediumnidad (1901). Dynamis, 35(1), 83-105. http://doi. org/10.4321/So211-95362015000100004

Graus, A. (2016). Discovering Palladino's mediumship: Otero Acevedo, Lombroso 
and the quest for authority. Journal of the History of the Behavioral Sciences, 52(3), 211-230. https://doi.org/10.1002/jhbs.21789

Houdini, H. (1924). Houdini exposes the tricks used by the Boston medium "Margery" to win the $\$ 2500$ prize offered by the Scientific American: Also a complete exposure of Argamasilla, the famous Spaniard who baffled noted scientists of Europe and America, with his claim to X-ray vision. Adams Press.

Janet, P. (1889). L'automatisme psychologique: Essai de psychologie expérimentale sur les formes inférieures de l'activité humaine. Félix Alcan.

Méndez Bejarano, M. (n.d., ca. 1925). Historia de la filosofía en España hasta el siglo $X X$. Renacimiento.

Moreman, C. M. (Ed.). (2013). The spiritualist movement: Speaking with the dead in America and around the world. (3 vols.). Praeger.

Mülberger, A. (Ed.). (2016). Los límites de la ciencia: Espiritismo, hipnotismo y el estudio de los fenómenos paranormales (1850-1930). Consejo Superior de Investigaciones Científicas.

Mülberger, A., \& Balltondre, M. (2013). En el umbral de lo desconocido: Un caso de visión extraordinaria en la España de Primo de Rivera. Dynamis, 33(1), 195-216. https://doi.org/10.4321/s0211-95362013000100009

Mülberger, A., Astudillo, S., Lorente, S., \& Martos, M. (2001). El Padre Palmés contra la metapsíquica: Un análisis histórico de su retórica defensiva. Revista de Historia de la Psicología, 22(3-4), 431-438.

Navarro Murillo, M. (1873-1874). El advenimiento de la nueva era de armonía. Revista Espiritista, 5(11, 12), 242-246, 257-26o; 6(1, 2, 3), 1-7, 25-32, 49-52.

Nicol, F. (1966). Clerical contributions to parapsychology. International Journal of Parapsychology, 8, 227-247.

Otero Acevedo, M. (1891, June 17, 22, 28, July 12, 19, 26, August 2, 9, 16, 22, 29, September 5). Los fantasmas. El Heraldo de Madrid, all on p. 1.

Otero Acevedo, M. (1893-1895). Los espíritus (2 vols.). Revista Psicológica "La Irradiación."

Podmore, F. (1902). Modern spiritualism: A history and a criticism (2 vols.). Methuen.

Primer Congreso Internacional Espiritista: Representaciones, adhesiones, sesiones públicas, sesiones privadas, conclusiones, documentos, etc.: Reseña completa (1888). Daniel Cortezo.

La queue du moyen âge: Auto-da-fe des ouvrages spirites à Barcelone. (1861). Revue Spirite, 4(11), 321-325.

Richet, C. (1922). Traité de métapsychique. Félix Alcan.

Santa Cara, Marqués de. (n.d., ca. 1924). Un tanteo en el misterio (Ensayo experimental sobre la lucidez sonambúlica). M. Aguilar.

Sharp, L. L. (2006). Secular spirituality: Reincarnation and spiritism in nineteenthcentury France. Lexington Books.

To members and associates of the Society for Psychical Research: Circular No. 
1. (2nd ed.). On the general work of the Society. (1883). Proceedings of the Society for Psychical Research, 1, 295-302.

Torres, H. (1923). La reencarnación. Lumen, 28(December), 309-318.

Torres-Solanot, [A.]. (1872). Preliminares al estudio del espiritismo: Consideraciones generales respecto a la filosofía, doctrina y ciencia espiritista. A. de San Martín.

Torres Solanot, [A.]. (1875). El movimiento espiritista. In Almanaque del espiritismo para el año de 1875 (pp. 68-70). Alcántara.

[Untitled article]. (1861, October 16). La Discusión, 1.

Vilaplana Traviera, E., \& Mülberger, A. (2003). Espiritismo, metapsíquica y ciencia: Análisis de tres aportaciones catalanas de principios del siglo XX. Revista de Historia de la Psicología, 24(3-4), 477-488. 